\title{
Right Inguinal Varicose Vein in Connection with Femoral Vein Following Intravenous Drug Abuse: A Rare Radiologic Finding
}

\author{
Ahmad Rezaee Azandaryani' ${ }^{1}$ Mehrdad Taghipour ${ }^{2}$, Leili Ebrahimi Farsangi ${ }^{{ }^{*}}$ \\ ${ }^{1}$ Radiology Department, Hamadan University of Medical Sciences, Beasat Hospital, Hamadan, Iran \\ ${ }^{2}$ Hamadan University of Medical Sciences, Beasat Hospital, Hamadan, Iran \\ ${ }^{3}$ Alborz University of Medical Sciences, Shahid Rajaee Hospital, Karaj, Iran \\ Email: *lilieage@gmail.com
}

How to cite this paper: Azandaryani, A.R., Taghipour, M. and Farsangi, L.E. (2017) Right Inguinal Varicose Vein in Connection with Femoral Vein Following Intravenous Drug Abuse: A Rare Radiologic Finding. Case Reports in Clinical Medicine, 6, 137-141.

https://doi.org/10.4236/crcm.2017.65013

Received: January 26, 2017

Accepted: May 20, 2017

Published: May 23, 2017

Copyright $\odot 2017$ by authors and Scientific Research Publishing Inc. This work is licensed under the Creative Commons Attribution International License (CC BY 4.0).

http://creativecommons.org/licenses/by/4.0/

\begin{abstract}
Varicose veins are enlarged, protuberant superficial veins that are palpable beneath the skin. The causes of such a venous pathology may be primary, secondary, or congenital. The major agents leading to the development of varicose veins include: Hereditary, prolonged standing, Increasing age, Heavy lifting, Prior superficial or deep vein clots, Female gender and Multiple pregnancies. In this manuscript, we report a case of inguinal varicose vein in connection with femoral vein, resulted from direct intravenous injection of drug. The diagnosis was made based on Doppler sonography.
\end{abstract}

\section{Keywords}

Substance Abuse, Intravenous, Varicose Vein

\section{Introduction}

Varicose veins are twisted, gnarled and swollen veins which are usually seen in lower extremities [1]. These are more common in women than men [2]. Some associated risk factors and causes are: obesity, pregnancy, menopause, aging, prolonged standing and leg injury. Some other factors also exist that are less pervasive like the direct intravenous injection [3] [4]. Intravenous drug abuse usually performs by drug users in the upper and lower extremities. Direct intravenous injection can have side effects which many of such cases have been reported so far. These include: infection, aneurysm, vascular necrosis and deep vein thrombosis. Based upon the radiologic texts, the present complication has relatively low incidence in general population and is valuable to be presented as a case report. 


\section{Case Presentation}

A 26-year-old male referred to the clinical center with a bulging and pain in right inguinal area (Figure 1). The sociodemographic and clinical characteristics of this patient are shown in Table 1. Hehas had a history of substance abuse intravenously in his femoral vein two years ago. He noted that he had not been injected in this area from two years ago. No special past medical history such as: local or systemic infection, chronic non-communicable diseases existed. On examination, the patient was not febrile. Vital signs were normal. In the physical examination, no lymphadenopathy was detected. The femoral, popliteal, and distal pulses were touched. Vascular packets with extension to the groin as well

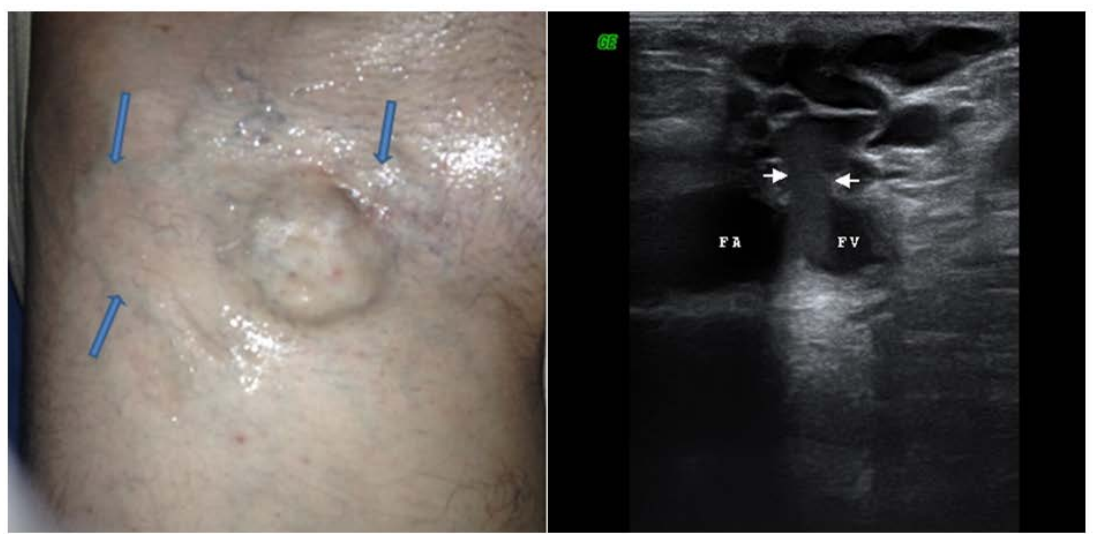

(a)

(b)

Figure 1. (a) Right inguinal demonstrates focal superficial protrusion, note prominent superficial veins at the periphery of the main lesion (arrows), (b) Gary scale ultrasound imsges from focal inguinal bulging demonstrates injection site (between arrows) connected femoral vein and varicose packets, FA (femoral artery), FV (femoral vein).

Table 1. Sociodemographic and clinical characteristics of the patient.

\begin{tabular}{|c|c|c|c|}
\hline Age (years) & 26 & $\begin{array}{l}\text { Side of vein } \\
\text { involvement }\end{array}$ & Right side \\
\hline Marital status & Divorced & Risk factors & $\begin{array}{l}\text { Smoking, local } \\
\text { injection }\end{array}$ \\
\hline $\begin{array}{l}\text { Monthly family } \\
\text { income }\end{array}$ & Less than $200 \$$ & $\begin{array}{l}\text { Conservative } \\
\text { management }\end{array}$ & $\begin{array}{c}\text { Limb elevation, } \\
\text { Compression } \\
\text { stockings }\end{array}$ \\
\hline Occupational status & Unskilled & $\begin{array}{c}\text { Medical } \\
\text { management }\end{array}$ & $\begin{array}{l}\text { Analgesics, Oral } \\
\text { anticoagulants }\end{array}$ \\
\hline Education & illiterate & Surgical procedures & $\begin{array}{l}\text { Saphenous vein } \\
\text { stripping }\end{array}$ \\
\hline Place of residence & Rural & & \\
\hline Signs & $\begin{array}{l}\text { Inguinal swelling, } \\
\text { vascular packets }\end{array}$ & & \\
\hline Symptoms & $\begin{array}{l}\text { Right inguinal area } \\
\text { bulging and pain }\end{array}$ & & \\
\hline
\end{tabular}


as prominent vessels around the mass were observed. The blood flows distributed from the femoral vein into the packets following Valsalva maneuver, and the direct connection with femoral vein was obvious. Dopler ultrasonographic evaluation conducted to assess the exact blood flow patterns and the existed connection between the femoral vein and varicose packets. Changes in blood flow after Valsalva maneuver was also represented in Figure 2. The patient was followed for treatment. At first, the patient underwent conservative management and then medical and surgical.

\section{Discussion}

The leading causative agent of varicose veins is unknown. It involves about sixty percent of the general population in the modern countries with further epidemiologic prevalence in women [5]. Here in the present paper, we report a case of 26-year-old male with varicose vein secondary to direct intravenous drug abuse diagnosed by duplex ultrasound.

The mechanisms of varicosity are not obviously clarified. Reflux and incompetency occurring in the vein valves, and also dilation of the vein wall are primarily lead to venous varicosis [6]. Once the vessel wall escalating tensionshappen, the expression/activity of matrix metalloproteinases (MMP) are also increasing [7]. Endothelial cell damage causes a cascade of leukocyte infiltration and inflammation, leading to more vein wall injury. In addition to the common risk factor for the disease like: prolonged standing, superficial or deep vein clots, female gender, multiple pregnancies, increasing age and heavy lifting; there are some other various factors that cause such disorders with mentioned mechanisms. Unusual etiologies of varicose veins in the lower extremities was evaluated in study conducted by Seung Chai Jung et al. [8]. They reported that the major rare factor of developing varicose vein was vulvoperineal varicosity, fol-

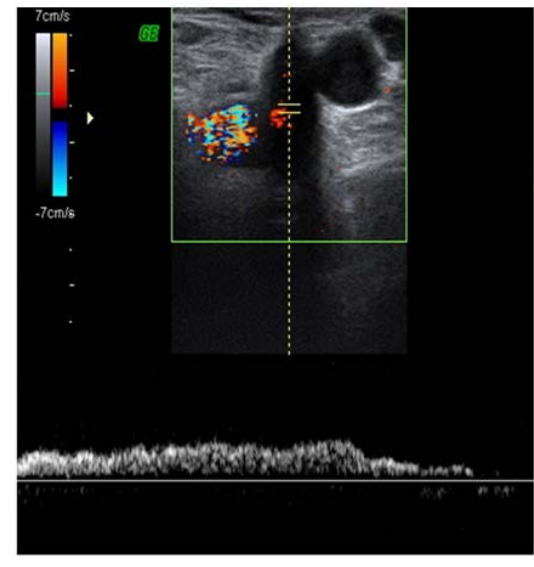

(a)

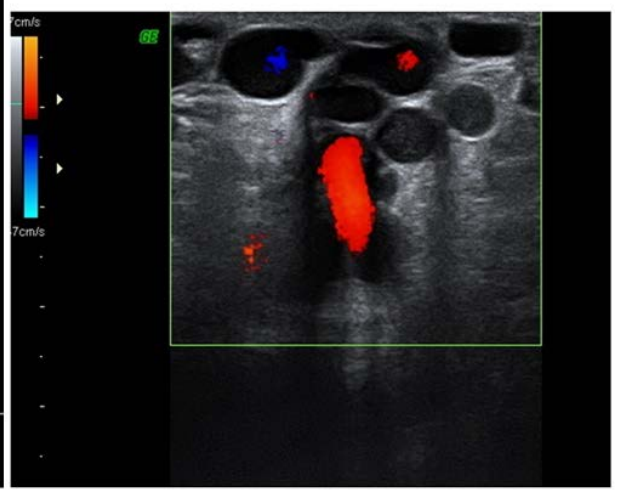

(b)

Figure 2. (a) Duplex ultrasound image after valsalva at injection site demonestrates venous Doppler pattern; (b) Color duppler ultransound images after valsalva maneuver from injection site demonstrates deep to superficial direction of flow, note engorged varicose packets also. 
lowed by round ligament varicosity, persistent sciatic vein incompetence, intraosseous perforating vein incompetence, Klippel-Trenaunay syndrome, congenital venous malformation, and portosystemic collateral-related varicose vein. In our study, the varicose vein packets developed following direct intravenous injecting in the femoral vein. Senbanjo et al. examined the types of drug used to inject in the groin and its local consequences and complicataions. The concluded that heroin was the most common drug with was abused and deep vein thrombosis was the most prevalent complication [9]. The diagnosis of the disease is not so difficult but the etiologic factor is important and always is questionable. Diagnosis is often delayed and patients are not managed precisely for long period of time.

\section{Conclusion}

This case report establishes new horizon for clinicians in order to consider more probable etiologic factors for venous disorders. Such unusual cases may be detected with the combined modalities of CT venography and Duplex sonography.

\section{Conflict of Interest Statement}

None of the contributing authors have any conflict of interest, including specific financial interests or relationships and affiliations relevant to the subject matter or materials discussed in the manuscript.

\section{References}

[1] Marsden, G., Perry, M., Kelley, K. and Davies, A.H. (2013) Diagnosis and Management of Varicose Veins in the Legs: Summary of NICE Guidance. BMJ, 347, f4279. https://doi.org/10.1136/bmj.f4279

[2] Fan, C.-M. (2005) Venous Pathophysiology. Seminars in Interventional Radiology, 22, 157-161. https://doi.org/10.1055/s-2005-921949

[3] Behera, A., Menakuru, S.R. and Jindal, R. (2003) Vascular Complications of Drug Abuse: An Indian Experience. ANZ Journal of Surgery, 73, 1004-1007. https://doi.org/10.1046/j.1445-2197.2003.t01-11-.X

[4] Pilkington, S.A., Rees, M., Jones, O. and Green, I. (2004) Ultrasound Diagnosis of Round Ligament Varicosities Mimicking Inguinal Hernias in Pregnancy. Annals of the Royal College of Surgeons of England, 86, 400-401. https://doi.org/10.1308/1478708041782094

[5] Parry, D.J., Aldoori, M.I., Hammond, R.J., Kessel, D.O., Weston, M. and Scott, D.J. (2002) Persistent Sciatic Vessels, Varicose Veins, and Lower Limb Hypertrophy: An Unusual Case or Discrete Clinical Syndrome? Journal of Vascular Surgery, 36, 396400. https://doi.org/10.1067/mva.2002.125844

[6] Bhatti, A.M., Siddique, K., Bashir, R.A., Sajid, M.T., Mustafa, Q.A. and Hussain, S.M. (2013) Unusual Causes of Secondary Varicose Veins. Journal of Ayub Medical College Abbottabad, 25, 81-85.

[7] Kalinin, R.E., Suchkov, I.A., Pshennikov, A.S., Kamaev, A.A. and Mzhavanadze, N.D. (2016) Concentration of Matrix Metalloproteinases and Magnesium Ions in Patients with Varicose Veins of Lower Limbs. Angiologiya i Sosudistaya Khirurgiya, 22, 24-28. 
[8] Jung, S.C., Lee, W., Chung, J.W., Jae, H.J., Park, E.A. and Jin, K.N. (2009) Unusual Causes of Varicose Veins in the Lower Extremities: CT Venographic and Doppler US Findings. Radiographics, 29, 525-536. https://doi.org/10.1148/rg.292085154

[9] Senbanjo, R., Tipping, T., Hunt, N. and Strang, J. (2012) Injecting Drug Use via Femoral Vein Puncture: Preliminary Findings of a Point-of-Care Ultra Sound Service for Opioid-Dependent Groin Injectors in Treatment. Harm Reduction Journal, 9, 6. https://doi.org/10.1186/1477-7517-9-6

Submit or recommend next manuscript to SCIRP and we will provide best service for you:

Accepting pre-submission inquiries through Email, Facebook, LinkedIn, Twitter, etc. A wide selection of journals (inclusive of 9 subjects, more than 200 journals) Providing 24-hour high-quality service User-friendly online submission system Fair and swift peer-review system Efficient typesetting and proofreading procedure Display of the result of downloads and visits, as well as the number of cited articles Maximum dissemination of your research work

Submit your manuscript at: http://papersubmission.scirp.org/ Or contact crcm@scirp.org 